\title{
PENANAMAN KARAKTER SISWA MELALUI RAGAM BAHASA DALAM KEGIATAN PEMBELAJARAN BAHASA INDONESIA
}

\author{
Mahsusi $^{1}$, Nuryani ${ }^{2}$, Ahmad Bahtiar ${ }^{3}$ \\ UIN Syarif Hidayatullah Jakarta \\ 1mahsusi@uinjkt.ac.idl; 2nuryani@uinjkt.ac.id; 3ahmad.bahtiar@uinjkt.ac.id
}

doi) https://doi.org/10.36052/andragogi.v9i1.226

Diterima: 31 Mei 2021 | Disetujui: 2 Juni 2021 | Dipublikasikan: 30 Juni 2021

\begin{abstract}
Abstrak
Penelitian ini betujuan untuk mendeskripsikan penanaman karakter melalui ragam bahasa yang digunakan dalam kegiatan pembelajaran Bahasa dan Sastra Indonesia di sekolah. Kegiatan pembelajaran merupakan kegiatan yang didominasi oleh penyampaian materi oleh guru. Dalam menyampaikan materi tersebut guru menggunakan bahasa yang beragam. Oleh karena itu, penggunaan bahasa yang beragam dapat dimanfaatkan juga sebagai cara untuk menanamkan karakter siswa. Metode penelitian yang digunakan dalam penelitian ini adalah deskriptif kualitatif. Lokasi penelitian ini adalah di SMA Triguna Utama dengan objek penelitian kelas XA pada pembelajaran Bahasa dan Sastra Indonesia. Metode pengumpulan data dilakukan dengan observasi langsung dalam kegiatan pembelajaran dan wawancara mendalam dengan siswa dan guru serta beberapa pihak yang terlibat dalam kegiatan pembelajaran. Temuan penelitian menjelaskan bahwa penggunaan ragam Bahasa oleh guru tersebut mampu menciptakan bermacam-macam situasi dan konteks yang berlangsung dalam pembelajaran. Ragam bahasa yang dipakai juga mampu digunakan untuk menanamkan karakter siswa baik di lingkungan kelas maupun di luar kelas. Ketika guru menggunakan bahasa dengan pilihan kata yang santun siswa juga akan mengikutinya. Demikian juga dalam konteks lain, ketika guru memilih menggunakan ragam bahasa yang akrab siswa juga akan mengikuti dengan pilihan bahasa akrab. Berdasarkan analisis yang dilakukan dapat disimpulkan bahwa dalam kegiatan pembelajaran ditemukan penggunaan ragam resmi (formal), konsultatif, santai, dan akrab.
\end{abstract}

Kata Kunci: karakter, ragam bahasa, pembelajaran Bahasa Indonesia

\begin{abstract}
This study aims to describe the character planting through the variety of languages used in Indonesian language and literature learning activities in schools. Learning activities are activities that are dominated by the delivery of material by the teacher. In delivering the material, the teacher uses a variety of languages. Therefore, the use of various languages can also be used as a way to instill student character. The research method used in this research is descriptive qualitative. The location of this research is Triguna Utama Senior High School with the research subjects of class XA on Indonesian Language and Literature learning. The method of data collection was carried out by direct observation in learning activities and in-depth interviews with students and teachers as well as several parties involved in learning activities. Based on the analysis carried out, it can be concluded that in learning activities, the use of formal (formal), consultative, relaxed, and familiar modes is found. The use of various languages by the teacher is able to create various situations and contexts that take place in learning. The variety of languages used can also be used to instill student character both in the classroom environment and outside the classroom. When the teacher uses language with polite choice of words, students will also follow. Likewise in other contexts when the teacher chooses to use a variety of familiar languages, students will also follow the familiar language choice.
\end{abstract}

Keywords: Character, language varieties, Indonesian Language learning

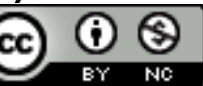

This work is licensed under a Creative Commons Attribution-NonCommercial 4.0 International License 


\section{PENDAHULUAN}

P elaksanaan pembelajaran menjadi kegiatan yang menjadi ujung tombak dalam pelaksanaan pendidikan. Di dalamnya memuat kegiatan yang tidak hanya terkait dengan kognitif melainkan juga afektif dan psikomotorik. Selain itu, dalam kegiatan pembelajaran juga melibatkan banyak pihak. Selain guru tentu di dalamnya ada keterlibatan dengan siswa dan pihak lain seperti tenaga kependidikan, tenaga kebersihan, maupun pihak lain yang masuk ke dalam kelas dalam situasi tertentu. Untuk itu, pelaksanaan kegiatan pembelajaran harus dirancang dan dilaksanakan secara serius guna mencapai tujuan pendidikan.

Guru dan siswa sebagai pihak utama yang terlibat dalam kegiatan pembelajaran menjadi poin penting dalam penanaman karakter. Seperti yang menjadi tujuan pendidikan bahwa pelaksanaan pendidikan harus mampu meciptakan perubahan hidup menjadi lebih baik. Akan tetapi, dewasa ini dunia pendidikan dihadapkan pada permasalahan nyata yang ditemui di kalangan pelajar. Beberapa kasus yang ditemui di antaranya adalah penggunaan narkoba di kalangan pelajar, tawuran, perundung, dan berbagai kasus negatif lainnya. Berbagai permasalahan tersebut tentu tidak hanya menjadi tanggung jawab keluarga sebagai pihak utama melainkan perlu juga adanya tanggung jawab oleh pihak sekolah dan agama (Martati, 2019 : 305). Dalam hal tersebut penyampaian mata pelajaran menjadi penting selain materi juga penanaman karakter. Oleh karena itu, guru memiliki tanggung jawab sebagai agen perubahan di dalam kelas. Siswa sebagai peserta didik menjadi agen "yang diubah" menjadi lebih baik.

Mengingat betapa pentingnya proses pembelajaran maka pelaksanaannya harus terencana dengan baik. Perencaan yang harus dilakukan salah satunya terkait dengan manajemen sekolah. Pelaksanaan manajemen sekolah yang efektif dan efisien akan menjadi cara yang bagus untuk melaksanakan kegiatan pembelajara secara terencana. Untuk pelaksanaannya diperlukan adanya perencanaan (planning), pengorgani-sasian (organizing), dan pengawasan (controling) yang dilaksanakan secara terintegrasi dan terpadu (Sari dan Mundilarno, 2020: 425). Keberhasilan dan keefektifan dari manajemen diharapkan akan menjadi kunci dari keberhasilan pelaksanaan proses pembelajaran di samping adanya faktor dari guru dan siswa.

Identitas guru menjadi salah satu topik yang menarik untuk dilteliti dari berbagai sisi. Guru memiliki kekuatan yang melampaui bayangannya sendiri termasuk dalam kemampuan menggunakan bahasa di dalam kelas Persiapan guru mengajar dalam bentuk Rencana Pelaksanaan Pembelajarn (RPP) terkadang hanya sebagai patokan utama. Sementara itu, dalam pelaksanaannya guru mampu melakukan eksplorasi secara lebih mendalam dan meluas sesuai dengan konteks pembelajaran yang berlangsung (hasil wawancara dengan guru pengajar di SMA Triguna Utama). Demikian juga dalam kemampuan mengeksplorasi kemampuan berbahasa guru juga memiliki kemampuan tersendiri. Para guru mengakui bahwa praktik komunikasi dengan multilingual (banyak bahasa) dalam kegiatan pembelajaran menjadi sebuah hal yang berharga yang harus diakui sebagai kebijakan berbahasa di kelas (Allard, et.al., 2019: 3). Kemampuan tersebut harus terus diasah dan dieksplor guna menciptakan suasana yang menyenangkan dalam pelaksanaan pembelajaran di dalam kelas. Selain itu, melalui kemampuan penggunaan ragam bahasa diharapkann guru mampu menjadi motivator yang menanamkan karakter baik dalam diri siswa.

Aktivitas pemmbelajaran pada dasarnya merupakan kegiatan atau tindakan baik fisik maupun metal yang dilakukan oleh individu untuk membangun pengetahuan dan keterampilan diri dalam kegiatan tersebut (Hartati, 2019: 291). Untuk menciptakan hal tersebut keterlibata guru dan siswa menjadi sangat penting. Guru diharapkan mampu mengelola kelas secara baik guna menciptkan pengetahuan yang bermakna bagi siswa sehingga mampu menumbuhkan keterampilan yang mampu digunakan dalam kehidupan sehari-hari. Melihat hal tersebut dapat disampaikan bahwa proses pembelajaran di kelas menjadi sebuah "ajang" menanamkan 
berbagai karakter dalam diri siswa. Tidak hanya karakter baik tetapi karakter yang buruk sangat mungkin dapat tumbuh dalam proses pelaksanaannya. Untuk itu, kemunculan karakter buruk harus mampu diminimalkan dengan beragam cara. Salah satu cara yang dapat diupayakan adalah dengan menggunakan ragam bahasa sebagai penngantar dalam pelaksanaan pelaksanaan pembelajaran.

Masyarakat Indonesia merupakan masyarakat yang multilingual. Hampir semua masyarakat menguasai lebih dari satu bahasa, yakni bahasa Indonesia dan bahasa daerah masing-masing. Terlebih di wilayah Tangerang Selatan yang merupakan wilayah rural. Sangat dimungkinkan banyak pendatang yang membawa bahasa daerah masing-masing, bahasa Betawi sebagai bahasa asli orang Jakarta dan sekitarnya, serta bahasa Indonesia yang digunakan sebagai pengantar. Melihat keunikan tersebut guru di wilayah rural ini juga harus mampu beragam bahasa sehingga mampu menciptakan kegiatan pembelajaran yang menarik sekaligus mampu menanamkan karakter yang baik dalam diri siswa. Bahkan kelas-kelas di Amerika Serikat guru-guru juga mengajar dengan menggunakan beragam bahasa mengingat kelas-kelas di sana melayani siswa dari beragam latar belakang budaya dan bahasa (Rowe, 2019: 1). Hal yang sama juga terjadi di Indonesia secara umum dan di Tangerang Selatan secara khusus. Sekolahsekolah di wilayah Tangerang Selatan sangat mungkin diisi oleh siswa dari beragam latar belakang budaya dan bahasa.

Keberagam latar belakang siswa menjadi tantangan tersendiri bagi. Guru diharapkan pandai-pandai dalam memilih metode pengajaran yang sesuai. Kesesuaian tersebut meliputi beberapa aspek yang harus dipertimbangkan. Salah satunya adalah keefektifan metode untuk menyampaikan materi dan pemanfaatannya untk menanamkan nilai-nilai karakater.

Penggunaan metode ceramah menjadi salah satu yang dapat dipertimbangkan. Meskipun banyak perdepatan atas penggunaan metode yang dianggap sudah sangat konvensional ini. Hamdayama, (2014: 169) menyampaikan beberapa kelebihan metode ceramah. Beberapa di antaranya adalah guru mudah menguasai kelas karena guru menyampaikan materi dan informasi secara langsung di depan peserta didik, mudah dilaksanakan, dan metode yang dianggap sangat ekonomis dan fleksibel. Meskpiun demikian, kelemahan metode ceramah jelas dianggapa sebagai metode yanng membosankan dan meyebabkan anak menjadi pasif.

Setiap metode memang memiliki kelebihan dan kelemahan masing-masing. Oleh karena itu, diharapkan guru untuk mampu menyesuaikan penggunaan metode dengan tepat. Seperti halnya dengan metode cermah. Karena bersifat verbalisme maka diperlukan kemampuan guru untuk mengolah kata dengan baik melalui pemilihan diksi dan ragam bahasa secara tepat. Hal tersebut akan membuat pembelajaran berjalan dengan menarik. Selain itu, dengan metode cermah yang menggunakan ragam bahasa yang baik maka penanaman karakter akan dapat diwujudkan.

Karakter sejatinya menjadi sesuatu yang penting untuk dimunculkan dalam setiap individu. Untuk itu, harus mendapatkan perhatian dari berbagai pihak, yakni orang tua, guru, dan tanpa terkecuali masyarakat pada umumnya. Dewasa ini, perihal karakter menjadi sangat memprihatinkan terlebih jika melihat perilaku warganet dalam bermedia sosial (Kusmanto, 2019: 119). Siswa sebagai generasi milenial pengguna media sosial terbanyak hendaknya mendapatkan pelajaran mengenai perilaku santun salah satunya dalam bermedia sosial. Hal tersebut sebagai perwujudan karakter yang baik dalam diri siswa. Mereka dapat memperoleh pelajaran tersebut salah satunya melalui contoh langsung dari bahasa yang digunakan oleh pengajar. Karena seperti disampaikan oleh Narwanti (2011: 63) bahwa implementasi pendidikan karakter di SMA salah satunya adalah melalui keteladanan, yakni perilaku/sikap semua warga sekolah yang dapat dijadikan panutan. Contohnya adalah tidak pernah terlambat, berpaikan rapi, bertutur kata sopan, gemar membaca, dan lain sebagainya.

Dalam pelaksanaannya di jalur pendidikan formal, pembangunan karakter dilakukan melalui restrukturisasi pendidikan moral di semua jenjang pendidikan dengan nomenklatur 
pendidikan karakter (Suyadi, 2013: 2). Akan tetapi, dalam pelaksanaan pengajaran pendidikan karakter dapat disampaikan atau terintegrasi dalam setiap mata pelajaran. Lebih jauh Suyadi (2013: 18-19) memberikan contoh bahwa penanaman nilai-nilai karakter dalam mata pelajaran Fisika. Guru memberikan soal sebagai berikut.

Jika seorang peserta didik berangkat sekolah pukul 06.30 WIB dengan sepeda yang berkecapatan $10 \mathrm{~km} / \mathrm{jam}$, pada pukul berapa peserta didiik tersebut akan sampai di sekolah jika jarak antara rumah dan sekolah adalah $5 \mathrm{~km}$ ? Jawabannya adalah pukul 07.00 WIB.

Berdasarkan contoh soal di atas guru, selain memberikan jawaban secara tepat berdasarkan hukum Fisika, juga dapat mentransmisikan ke dalam nilai karakter disiplin. Siswa harus tahu jarak rumah dan sekolah sehingga berusaha untuk tidak terlambat. Selain pada mata pelajaran Fisika penanaman nilai-nilai karakter juga dapat diintegrasikan melalui mata pelajaran Bahasa Indonesia. Wibowo (2013: 161) menyampaikan bahwa internalisasi nilai-nilai karakter bangsa akan efektif disampaikan melalui pengajaran sastra. Hal tersebut tentu harus didukung oleh guru yang memiliki kemauan dan penjiwaan terhadap sastra secara baik.

Berdasarkan penjelasan di atas maka dapat disampaikan bahwa penanaman nilai-nilai karakter siswa sejatinya menjadi tanggung jawab semua pihak salah satunya adalah sekolah. Sekolah diharapkan mampu menjadi agen perubahan dan pembangun karakter positif dalam diri siswa. Oleh karena itu, ketersediaan sarana dan prasarana sebagai penunjang penanaman karakter tersebut harus menjadi prioritas.

Berbicara mengenai sarana dan prasarana, pembelajaran tidak dapat dilepaskan dari ketersediaan buku teks. Selain keberadaan guru, keberadaan buku teks menjadi sebuah hal yang wajib dalam setiap kegiatan pembelajaran. Untuk itu, buku teks juga harus menjadi saah satu instrumen untuk menanamkan nilai-nilai karakter siswa. Nuryani, (2015: 525) menyampaikan bahwa dalam buku teks pada dasarnya telah mencerminkan nilai-nilai karakter tetapi belum semua dapat tersampaikan dan terpahami dengan baik. Hal tersebut dikarenakan buku teks hanya menjadi rujukan yang kurang dijelaskan secara baik oleh guru. Di sinilah peran penting penggunaan ragam bahasa oleh guru untuk menjelaskan segala aspek pembelajaran dengan pemilihan kata yang tepat. Karena pada dasarnya guru harus memiliki keluwesan dalam mengelola kelas dengan menggunakan banyak cara, salah satu yang dapat dilakukan adalah dengan bermain ragam bahasa.

Seperti yang terlihat di SMA Triguna Utama yakni guru memiliki keluwesan tersendiri dalam menngolah kata. Hal tersebut menjadikan interaksi di kelas terasa lebih "hidup." Interaksi digunakan untuk membangun suasana pembelajaran untuk lebih menyenangkan. Dalam konteks lain guru menggunakan bahasa sebagai sarana menanamkan nilai-nilai kebaikan dalam diri siswa. Istilah yang mungkin dapat lebih mudah adalah brainwash dalam arti memasukkan ke dalam diri siswa karakterkarakter baik yang secara alami tidak mereka sadari. Dalam konteks lain pula penggunaan bahasa terkadang dapat digunakan untuk menanamkan ideologi tertentu (Rowe, 2019: 2). Pada kegiatan pembelajaran ini guru juga berupaya menggunakan bahasa untuk membangun karakter dan ideologi yang baik dalam diri siswa.

Pemerintah pusat melalui Pusat Kurikulum (2009: 9-10) telah merumuskan setidaknya delapan belas karakter yang diharapkan dapat terinternalisasi dalam diri siswa. Delapan belas karakter tersebut adalah religius, jujur, toleransi, disiplin, kerja keras, kreatif, mandiri, demokratis, rasa ingin tahu, semangat kebangsaan, cinta tanah air, menghargai prestasi, bersahabat/komunikatif, cinta damai, gemar membaca, peduli lingkungan, peduli sosial, dan tanggung jawab. Tidak mungkin kedelapan belas karakter tersebut muncul secara bersamaan dalam setiap tuturan. Akan tetapi, diharappkan dalam setiap ragam bahasa yang digunakan baik oleh guru maupun siswa merupakan cerminan atau manifeestasi dari salah satu karakter tersebut. Dengan demikian, nilai-nilai tersebut telah terinternalisasi secara baik dalam diri siswa.

Ragam bahasa dalam kajian lingusitik masuk dalam ranah kajian Sosiolinguistik. Kajian ini mengambil bahasa sebagai obyek 
kajian dan menganalisisnya sebagai bagian dari property social (Jendar, 2010: 10). Bahasa yang digunakan oleh guru dan siswa dalam pembelajaran menjadi obyek dalam kajian ini karena sebagai bagian dari aset sosial. Selain ragam bahasa, beberapa kajian yang dikaji dalam Sosiolinguistik di antaranya identitas sosial penutur, tingkatan variasi dan ragam bahasa, dan analisis sinkronik maupun diakronik.

Variasi bahasa didefinisikan sebagai wujud perubahan atau perbedaan dari berbagai manifestasi kebahasaan tetapi tidak bertentangan dengan kaidah kebahasaan (Nuryani, Isnaniah, dan Eliya, 2021 : 84). Hal tersebut dapat diartikan ketika dalam komunikasi penutur menggunakan variasi bahasa yang beragam maka tidak dikategorikan sebagai kesalahan maupun melanggar kadiah kebahasaan yang berlaku. Ragam bahasa tersebut digunakan untuk membangun komunikasi dan interaksi supaya berjalan dengan baik. Penggunaannya melihat konteks dan situasi yang melatarbelakanginya.

Kemunculan ragam bahasa disebabkan oleh adanya kegiatan interaksi sosial yang dilakukan kelompok yang beragam dan karena penutur yang tidak homogen. Hal itulah yang sering menjadi alasan ketertarikan untuk melihat kajian variasi bahasa sebagai bagian dari Sosiolinguistik. Terdapat berbagai jenis variasi bahasa menurut para linguis. Dalam kajian ini penulis memanfaatkan teori yang disampaikan oleh (Jendar, 2010: 98) yang membagi variasi bahasa berdasarkan segi keformalan. Dari segi keformalan terdapat lima jenis variasi bahasa, yakni.

a. Ragam Baku

Ragam ini adalah jenis variasi bahasa yang paling formal. Bahasa yang digunakan tidak dapat diubah sesuai dengan keinginan individu. Ragamnya sudah baku sebagai ciri khas suatu bidang. Konteks penggunaan ragam ini adalah saat situasi-situasi khidmat atau upacara resmi. Sebagai contoh adalah dalam upacara keagamaan, khutbah, kitab undang-undang, dan surat-surat keputusan.

b. Ragam Resmi

Ragam ini juga disebut sebagai ragam formal. Artinya, bahasa yang digunakan dapat diubah sesuai keinginan individu tetapi dengan memperhatikan situasi. Konteks penggunaan ragam ini dapat kita temui seperti dalam pidato kenegaraan, rapat dinas, surat menyurat dinas, dan buku-buku pelajaran.

c. Ragam Usaha

Ragam ini juga dikenal dengan ragam konsultatif. Ragam usaha sering kita temui dalam kegiatan pembicaraan di sekolah, baik dalam situasi pembelajaran maupun di luar kelas, dan pembicaraan yang berorientasi kepada hasil produksi.

d. Ragam Santai

Ragam santai biasa digunakan dalam situasi yang tidak resmi. Penutur dan mitra tutur bisa saja memiliki hubungan yang tidak terlalu dekat tetapi dalam situasi dapat memunculkan atau menggunakan ragam ini.

\section{e. Ragam Akrab}

Ragam ini digunakan oleh penutur dan mitra tutur yang memiliki hubungan sudah akrab atau intim. Beberapa di antaranya hubungan keluarga dan teman yang sudah seperti keluarga.

Beberapa penelitian terkait dengan ragam bahasa pernah dilakukan oleh peneliti sebelumnya. Di antaranya adalah oleh Alamsyah, (2007) dan Puspitasari, Dhika, dan Furinawati, (2015) (2015). Alamsyah melihat ragam bahasa guru dalam interaksi pembelajaran. Sementara itu, Puspitasari melihat pada karakteristik pemakaian bahasa guru dalam proses belajar mengajar. Berdasarkan kedua penelitian yang telah dilakukan tersebut penulis melihat adanya kesenjangan pada penanaman karakter. Kedua penelitia sebelumnya belum menyentuh pada ranah karakter. Oleh karena itu, permasalahan dalam penelitian ini adalah bagaimana penanaman karakter melalui ragam bahasa dalam kegiatan pembelajaran. Tujuan dalam penelitian ini adalah untuk mendekripsikan penanaman karakter melalui ragam bahasa dalam kegiatan pembelajaran.

\section{METODE PENELITIAN}

\section{Metode Penelitian}

Penelitian ini menggunakan metode deskriptif kualitatif. Dengan metode tersebut memungkinkan peneliti untuk menyampaikan data secara apa adanya sesuai fakta dan 
peristiwa yang terjadi di lapangan. Selain itu, data yang dikumpulkan berupa bahasa, yakni kata-kata dan kalimat sehingga sangat mungkin untuk menggunakan metode kualitatif. Beberapa hal yang menjadi landasan pemilihan metode kualitatif adalah lingkungan alamiah sebagai sumber data, manusia sebagai instrumen atau alat pengumpul data, tekanan penelitian berada pada proses, perencanaan bersifat lentur dan terbuka, dan data yang diperoleh berupa kata-kata, gambar, dan perilaku.

\section{Objek dan Subjek Penelitian}

Obyek yang dikaji dalam penelitian ini adalah ragam bahasa yang digunakan oleh guru saat mengajar dan siswa saat memberikan tanggapan. Selain itu, obyek ang dikaji juga dalam penelitian ini adalah karaketr-karakter yang muncul dari ragam bahasa yang digunakan oleh subyek penelitian.

Subyek penelitian ini adalah siswa dan guru yang terllibat dalam penelitian ini. Selain itu, data tambahan peneliti juga melakukan wawancara terhadap mahasiswa dari UIN Syarif Hidayatullah Jakarta yang sedang melaksanakan praktik mengajar di kelas tersebur. Guru yang menjadi subyek penelitian adalah guru pengampu mata pelajaran Bahasa dan Sastra Indonesia di kelas $X$. Demikian juga dengan siswa yang menjadi subyek penelitian adalah siswa kelas XA.

\section{Teknik Pengumpulan Data dan Pengembangan Instrumen}

Teknik pengumpulan data yang digunakan meliputi obeservasi langsung di kelas saat pembelajaran dan wawancara mendalam dengan guru, siswa, dan mahasiswa praktik. Wawancara juga digunakan sebagai triangulasi data.

Mengingat penelitian ini adalah penelitian kualitatif maka peneliti sendiri yang berperan sebagai instrumen. Penelitia dibantu oleh dua orang asisten peneliti untuk melakukan catatan lapangan dan transkripsi data.

\section{Waktu dan Tempat Penelitian}

Penelitian ini dilakukan pada Mei 2019 dengan mengambil sebanyak empat kali observasi. Empat kali observasi dilakukan bersamaan dengan empat kali pertemuan pembelajaran Bahasa Indonesia. Sementara itu, lokasi penelitian ini di SMA Triguna Utama yang terletak di Jl. Ir. H. Djuanda, Ciputat, Tangerang Selatan. Sekolah ini berafiliasi dengan UIN Syarif Hidayatullah Jakarta.

\section{Teknik Analisis Data}

Analisis data dilakukan secara induktif. Analisis ini dilakukan dengan dimulai peneliti terjun ke lapangan, mengambil data, mempelajari, menganalisis, menafsirkan, dan kemudian membuat simpulan dari fenomena di lapangan.

\section{TEMUAN DAN PEMBAHASAN}

\section{Temuan}

Berikut akan disajikan temuan dari lapangan yang berupa ragam bahasa. Data disajikan dalam bentuk transkripsi data ketika pembelajaran berlangsung. Data yang disajikan dalam temuan data ini tidaklah seluruh data mengingat data yang terkumpul sangat banyak. Temuan ini berdasarkan hasil dari transkripsi dan kemudian peneliti melakukan klasifikasi.

A. Pembelajaran berlangsung pada Kamis, 9

Mei 2019 pukul 08.00-09.30. Materi: Puisi Guru: Masih ingat pelajaran kemarin?

Siswa: masih ...

Guru: coba angkat tangan yang tahu tentang unsur-unsur puisi?

Siswa: saya Pak.

Guru: Ya, coba jelaskan!

Siswa: Eh, enggak jadi dah.

Guru: Ayo yang berani angkat tangan, saya kasih bengbeng.

Siswa: Saya Pak (beberapa siswa sambil mengangkat tangan)

Guru: Oke, ini dulu. Apa yang kamu tahu tentang puisi?

Siswa: terdapat unsut intrinsik.

Guru: apa itu unsur intrinsik?

Siswa: Emmmm.... Tema, terus pelarikan, sajak, irama, alur, eh gak ada alur. Ituan, sudut pandang, eh bukan deh, jenis puisi itu.

Guru: coba buka buku kalian, kita cek di bab unsur puisi!

Guru: kita ulangi lagi ya... siapa yang bisa melengkapi? 
Siswa: pembaitan, pelarikan, tema, dan amanat.

B. Pembelajaran berlangsung pada Jumat, 10 Mei 2019 pukul 07.30-09.00.

Materi: Puisi (lanjutan)

Guru: Baik, kemarin kita sudah membahas tentang puisi dan unsur-unsurnya. Coba apa ada yang mau ditanyakan?

Siswa: (semua siswa diam)

Guru: bener ini tidak ada yang mau ditanyakan? Kalau tidak ada gantian saya yang bertanya ya. (sambil tersenyum)

Siswa: Yah.... Pak

Guru: Perlu kalian tahu, puisi itu hampir sama dengan lagu.

Siswa: Kenapa sama Pak?

Guru: Karena puisi bisa dijadikan lagu dan lagu bisa dijadikan puisi dengan syarat dan ketentuan yang berlaku.

Siswa: Hahaha... kayak paket data Pak.

Guru: lya betul, semuanya sekarang begitu, pasti ada syarat dan ketentuan yang berlakunya.

(Suasana kelas menjadi riuh oleh suara-suara, baik yang menanggapi maupun yang sekadar tertawa).

Guru: Baik, sekarang kita akan mendengarkan pemutaran lagu yang nanti akan kalian analisis. (Pemutaran lagu Iwan Fals berjudul “IBU)

C. Pembelajaran berlangsung pada Selasa, 14 Mei 2019 pukul 13.00-14.30.

Materi: Presentasi unsur intrinsik

Guru: Kemarin kita sudah mendengarkan pemutaran lagu dan sudah membuat kelompok untuk presentasi. Sebelum mulai presentasi coba ada yang mau disampaikan?

Siswa: Hiji deui Pak laguna

Siswa: Iya Pak, sekali lagi Pak (hampir semua siswa)

Guru: Baik, coba kita dengarkan lagi tapi tidak utuh ya.

(Memutarkan lagu dari awal-pertengahan lagu).

Guru: Ada yang tidak paham? Ayo acungkan tangan!

Siswa: Jadi yang dianalisis itu semuanya Pak?

Guru: (Guru membaca beberapa hasil analisis siswa yang telah dikumpulkan)

Oke, ini contoh analisisnya sudah ada yang bagus. Tapi enggak semua kita tumpahkan dalam bentuk argumen. Cari sisi yang kamu kuasai yang mana.

Siswa: Masih agak bingung deh Pak, jadi kalau kita kuasai mengenai rasa boleh kita menjelaskan mengenai rasa itu saja?

Guru: Iya betul. Jadi rasa itu apa?

Siswa: perasaan penyair?

Guru: iya boleh. Rasa itu perasaan penyair terhadap objek atau judul puisi. Coba tadi apa rasa itu, Anastasya?

Siswa A: Apaan Pak? Apaan? Gak paham Pak. Guru: Apa yang harus kita kerjakan? 0ke, kita pelan-pelan saja. Perhatikan, materi unsur instrinsiknya sudah ada sekarang kita tinggal analisis unsur instrinsiknya dari lagu tersebut. Kalau kalian analisis semuanya, nanti kan kalian punya waktu untuk menyampaikan argumen di diskusi jadi tidak semua disampapaikan.

Siswa: Pak, boleh ditambahin?

Guru: Awas, perhatikan, kita tidak sedang mengubah lirik lagu tetapi menganalisis lirik.

Siswa: 00000 gitu.

Guru: 00000 bulet

D. Pembelajaran berlangsung pada Kamis, 16 Mei 2019 pukul 08.0009.30 .

Materi: presentasi unsur intrinsik (lanjutan)

Guru: Kita lanjutkan untuk presentasi, kemarin sudah sampai kelompok 3 , hari ini tinggal 3 kelompok. Ada yang mau memberi tanggapan dulu untuk 3 kelompok kemarin? Boleh acungkan tangan.

(salah seorang mengangkat tangan)

Siswa: Saya Pak. Kemarin kalau tidak salah kelompok 2 bilang rasa lagu itu menyedihkan, bukannya kayak gitu tergantung pendengarnya ya Pak?

Guru: lya betul, kelompok 2 sebagai pendengar merasakan kalau lagu itu sedih, yang pendengar lain boleh memiliki rasa yang lain. Tapi ingat, harus dibuktikan dengan lirik yang mana? Kalau ada pendengar yang merasakan bahagia dengan lirik itu, bagian mana buktinya? Paham?

Siswa: hampir.... (serempak dan sambil senyum-senyum)

Guru: Oke kalai begitu, bisa lanjut ke kelompok selanjutnya?

Kelompok siswa presentasi (yang mewakili $\mathrm{Ni}$ Wayan Niken: 
Saya Ni Wayan Niken dan teman saya Nabila Lujingga. Jadi pada lagu Iwan Fals ini bertemakan pengorbanan seorang ibu untuk anaknya. Dalam lirik ini kita mendapatkan fakta pengorbanan seorang ibu yaitu pada lirik walau tapak kai penuh darah penuh nanah. Dan amanat pada lagu ini yaitu sayangilah ibu karena seorang ibu bisa merawat sepuluh atau lebi anak tetapi sepuluh anak mungkin tidak bisa merawat seorang ibu. Terima kasih.

Guru: jadi supaya lebih jelas, setiap anak silahkan mengeluarkan argumennya masingmasing! Ayoooo jangan takut.

Siswa: tema dari musik itu, kasih sayang dan pengorbanan ibu. Tertera dalam lirik ibuku sayang-penuh darah. Kata konfliknya ingin kudekap dan penuh nanah. Amanatnya kasih sayang seorang ibu takkan pernah ada batasnya sampai kapanpun. Di sini ibu terus berjuang sampai anaknya sukses, walaupun banyak rintangan yang menerjang.

Guru: oke bagus. Ayoooo siapa lagi? (diam sejenak, lalu melanjukan karena tidak ada siswa yang bersuara) Jadi sejauh ini rata-rata anakanak sudah memahami mengenai tema dari lagu yang telah diputar tadi. Pembelajarannya yaitu sejauh mana kita berhasil memahami apa yang kita pelajari.

Siswa yang presentasi melanjutkan: Saya mau ngambil tema tentang jasa seorang ibu. Yang mana pengorbanan seorang ibu dalam lirik ini tak mampu kumembalas karena pada saat kita kecil dan belum bisa apa-apa. Ibu sangat berperan untuk hidup kita, dia memberi asi, menjaga kita serta rela mengorbankan jam tidurnya. Jadi menurut kami jasa ibu tak akan terbalasa dengan apapun. Terima kasih.

Siswa lain menambahkan: Kasih sayang ibu kepada seorang anak yang tertulis dalam lirik lagu Iwan Fals ribuan kilo jalan yang kau tempuh, lewati rintang untuk aku anakmu. Dan juga rasanya ini sedih. Amanatnya yaitu kita harus menghargai seorang ibu, karena jasa seorang ibu takkan terbalas oleh apapun. Ibu itu tak mungkin kita balas dengan uang yang kita raih, itu gak mungkin.

Guru: sebentar saya potong, rasanya sedih itu yang mana? Supaya semakin sadar, argumennya itu bilang dalam lagu tersebut rasanya sedih. Lirik yang mana yang menyatakan tentang kesedihan?
Siswa: itu dii ingin ku mendekap dan menangis di pangkuanmu.

Guru: udah di lirik itu ya? Tapi mungkin sedihnya lebih sedikit yah. Lebih banyak hal lainnnya dibandingkan sedihnya. Ini kan sedang menggambarkan pengorbanan dan kasih sayang seorang ibu dan bla... bla... bla...

Siswa: Jadi temanya itu perjuangan dan kasih sayang seorang ibu. Amanatnya di dalam lagu itu betapa besarnya pengorbanan seorang ibu dan sampai kapanpun anak em jadi sampai gede pun ibu itu masih ngedukung dia, di lirik itu contohnya tuh em lalu doa-doa...

Guru: iya terima kasih. Awas, kita menyimpulkan kata-kata yang tidak pasti ya, hati-hati. Misalnya kata-kata pengorbanan yang ada dalam lirik ini. Ya demikianlah pembelajaran kita hari ini, bapak rasa cukup. Jadi kita dapat menyimpukan bersama-sama bahwa lirik lagu Iwan Fals ini yang berjudul "IBU" menggambarkan tentang bagaimana besarnya jasa seorang ibu, serta kasih sayangnya yang tak pernah dapat terbalaskan oleh apapun. Dan amanat yang bisa kita ambil yaitu bahwa kita sebagai seorang anak tidaklah pantas melawan seorang ibu, karena tanpa adanya seorang ibu kita bukanlah siapa-siapa. Maka anak-anak jangan samai kita menjadi anak yang durhaka ya, sekian. Wasalamualaikum warahmatullahi wabarakatuh dan selamat siang.

\section{Pembahasan}

Pembahasan akan didasarkan pada data yang disajikan dalam temuan di atas. Berdasarkan data tersebut penulis akan membahas berdasarkan ragamnya dan kemudian dilihat karakter yang muncul dari ragam bahasanya.

Kegiatan pembelajaran diawali ketika guru telah masuk ruang kelas. Di setiap pembelajaran terdapat beberapa kegiatan yang sama yang dilakukan oleh guru. Kegiatan tersebut adalah membuka kelas dengan mengucapkan salam, mengajak berdoa bersama, menanyakan kabar, memberikan motivasi, dan mengulang materi pada pertemuan sebelumnya. Untuk kegiatan mengajak berdoa bersama guru kemudian meminta salah satu siswa untuk memimpin doa.

Pada beberapa kegiatan rutin tersebut guru cenderung menggunakan ragam bahasa yang 
sama. Ragam bahasa yang muncul hanya ragam resmi. Berikut contoh kutipan tuturan guru di beberapa kegiatan tersebut.

Guru: Asalamualaikum warahmatullahi wabarakatuh.

Siswa: Waalaikum salam warohmatullahi wabarokatuh.

Guru: selamat pagi anak-anak, ada yang belum sarapan hari ini?

Siswa: pagi Pak... adaaaa (serempak)

Siswa: Bapak mau traktir? (salah satu siswa).

Berdasarkan contoh kutipan tuturan di atas muncul penanaman nilai karakter relijius yang muncul dari ucapan salam sebagai seorang muslim. Ucapan tersebut menjadi penting, yakni selain menjadi "sekadar" basi basi sebagai pembuka percakapan di kelas juga sebagai pembiasaan memberikan salam sebelum memulai sesuatu. Kelas yang menjadi lokasi penelitian tidak semuanya siswa beragama Islam. Terdapat siswa yang beragama lain seperti Kristen dan Hindu. Untuk itu, selain mengucapkan salam dalam agama Islam guru juga menyapa dengan menggunakan sapaan "Selamat pagi". Hal tersebut dilakukan guna menghormati siswa yang beragama lain meskipun sifatnya adalah minortitas. Hal tersebut jelas dilakukan untuk menanamkan karaker toleransi di dalam kelas.

Selain itu, karakter yang muncul lainnya adalah bersahabat/komunikatif. Karakter tersebut muncul melalui tuturan ketika guru menanyakan mengenai adakah siswa yang belum sarapan. Tuturan tersebut tidak hanya sekadar untuk mengetahui tentang siswa yang belum sarapan tetapi lebih pada "jembatan" awal untuk memulai interaksi yang lebih jauh. Untuk itu, karena kegiatan atau tuturan tersebut muncul di setiap pembelajaran maka di setiap kegiatan pembelajaran memunculkan karakter relijius.

Pada data A terdapat beberapa ragam bahasa yang digunakan oleh guru dan siswa. Ragam bahasa yang muncul adalah ragam resmi, ragam konsultatif, dan ragam santai. Kemunculan ketiga ragam bahasa tersebut digunakan baik oleh guru maupun siswa. Dalam ketiga ragam bahasa yang digunakan tersebut memunculkan penanaman karakter relijius, toleransi, disiplin, kerja keras, menghargai prestasi, tanggung jawab, dan cinta tanah air.
Contoh kemunculan ketiga ragam dan karakter yang muncul dapat dilihat pada kutipan contoh berikut ini.

Siswa: terdapat unsut intrinsik.

Guru: apa itu unsur intrinsik?

Siswa: Emmmm.... Tema, terus pelarikan, sajak, irama, alur, eh gak ada alur. Ituan, sudut pandang, eh bukan deh, jenis puisi itu.

Guru: coba buka buku kalian, kita cek di bab unsur puisi!

Guru: kita ulangi lagi ya... siapa yang bisa melengkapi?

Kutipan tuturan di atas terdapat ragam resmi yang digunakan dalam buku-buku pelajaran. Ketika guru dan siswa membaca buku teks tersebut guru dan siswa sedang menggunakan ragam resmi. Selain itu, muncul juga ragam konsultatif atau usaha, yakni ragam bahasa yang biasa digunakan dalam interaksi di kelas. Guru menggunakan bahasa yang semiformal yang didalamnya tidak mencampurkan dengan istilah-istilah non-formal. Guru juga menggunakan kalimat tanya dengan struktur yang lengkap, yakni diawali dengan kata tanya. Ragam santai merupakan ragam bahasa yang mendominasi dalam kegiatan pembelajaran tersebut. Hal tersebut dilakukan karena guru sudah merasa akrab dan dekat dengan siswa. Selain itu, guru sengaja menggunakan lebih banyak ragam santai supaya siswa tidak takut untuk menyampaikan pendapat dan argumennya (didapatkan keterangan setelah melakukan triangulasi data dengan wawancara terhadap guru).

Karakter disiplin yang muncl ditandai dengan bahasa pengantar guru di awal pertemuan bahwa siswa sebisa mungkin melakukan kegiatan makan pagi. Selain itu, karakter tersebut juga muncul melalui tuturan guru tentang adab jika mau bertanya siswa diminta untuk mengangkat tangan terlebih dahulu. Dengan begitu siswa akan terbiasa melakukan disiplin dalam kehidupan mereka. Guru juga berusaha memunculkan karakter kerja keras dengan ikut memberi semangat siswa dan selalu mendorong siswa untuk berpendapat. Dengan begitu, mereka tidak akan mudah berputus asa atau menyerah. Hal tersebut dapat dilihat dari tuturan guru "Ayo yang berani angkat tangan saya berikan Bengbeng". Dalam tuturan tersebut juga 
memunculkan karakter menghargai prestasi. Guru memberikan penghargaan berupa hadiah ketika siswa berani memberikan tanggapannya. Selain dalam tuturan tersebut kemunculan karakter menghargai prestasi juga dilakukan guru dengan menyampaikan "Baik" sebagai apresiasi atas jawaban atau tanggapan siswa.

Perwujudan karakter tanggung jawab juga terlihat dari tuturan guru ketika memberikan petunjuk kepada siswa untuk mengulang kembali jawabannya. Hal tersebut membiasakan siswa menghindar dari segala yang seharusnnya menjadi tanggng jawab mereka. Guru dapat menggunakan tuturan "Coba ulangi jawabanmu!" atau "Apa pendapatmu jika seperti ini?" dan beberapa tuturan yang lain. Siswa juga menunjukkan rasa cinta tanah air dengan menggunakan bahasa daerah Sunda. Penggunaan bahasa daerah tersebut bukan sesuatu yang tidak sengaja melainkan bentuk dari ekspresi langsung akan kecintaan terhadap daerahnya.

Pada data $B$ terdapat penggunaan ragam bahasa yang meliputi ragam ragam konsultatif, ragam akrab, dan ragam santai. Sementara itu, karakter yang ditanamkan berupa rasa ingin tahu, toleransi, demokratis, mandiri, relijius, gemar membaca, dan kreatif. Berikut kutipan contoh penggunaan ragam bahasa yang muncul dan yang mencerminkan karakter yang ditanamkan.

Guru: Karena puisi bisa dijadikan lagu dan lagu bisa dijadikan puisi dengan syarat dan ketentuan yang berlaku.

Siswa: Hahaha... kayak paket data Pak.

Guru: lya betul, semuanya sekarang begitu, pasti ada syarat dan ketentuan yang berlakunya.

(Suasana kelas menjadi riuh oleh suara-suara, baik yang menanggapi maupun yang sekadar tertawa).

Guru: Baik, sekarang kita akan mendengarkan pemutaran lagu yang nanti akan kalian analisis.

Pada data $C$ ditemukan penggunaan ragam bahasa yang meliputi ragam resmi, ragam konsultatif, dan ragam santai. Untuk nilai karakter yang berusaha ditanamkan melalui penggunaan ragam bahasa ada karakter relijius, jujur, disiplin, dan kreatif. Kemunculan ragam bahasa dan pencerminan nilai karakter dapat dilihat pada contoh kutipan berikut.
Guru: Ada yang tidak paham? Ayo acungkan tangan!

Siswa: Jadi yang dianalisis itu semuanya Pak? Guru: (Guru membaca beberapa hasil analisis siswa yang telah dikumpulkan)

Oke, ini contoh analisisnya sudah ada yang bagus. Tapi enggak semua kita tumpahkan dalam bentuk argumen. Cari sisi yang kamu kuasai yang mana.

Siswa: Masih agak bingung deh Pak, jadi kalau kita kuasai mengenai rasa boleh kita menjelaskan mengenai rasa itu saja?

Pembelajaran yang berlangsung dalam data D merupakan pembelajaran dengan materi presentasi. Siswa diminta untuk mempresentasikan hasil analisis yang mereka lakukan terhadap lirik lagu yang telah diputarkan sebelumnya. Karena materi itulah maka ragam bahasa yang muncul hanya ragam santai dan konsultatif.

Ragam santai muncul karena kegiatan lebih banyak dilakukan dengan diskusi. Dalam diskusi guru dan siswa cenderung menggunakan bahasa yang santai supaya diskusi dapat berjalan dengan lancar. Siswa lebih tenang dan santai dalam mengungkapkan argumen atau pendapatnya. Hal tersebut terbukti ketika ternyata banyak siswa yang mampu menyampaikan argumennya secara baik dan runtut.

Ragam konsultatif muncul secara pasti karena kegiatan tersebut berlangsung di kelas. Guru dan siswa cenderung lebih memperhatikan pilihan kata yang digunakan. Meskipun muncul pilihan kata tidak baku tetapi kemunculannya tidak terlalu banyak. Hal tersebut lebih dipengaruhi oleh situasi yang santai yang terbangun pada saat pembelajaran berlangsung. Oleh sebab itu, kedua ragam bahasa ini digunakan secara bersamaan dalam beragam situasi dan konteks.

Penggunaan ragam bahasa oleh guru dan siswa tersebut memunculkan wujud karakter yang beragam pula. Karakter yang terwujud berupa kreatif, relijius, toleransi, tanggung jawab, dan menghargai prestasi. Kemunculan karakter sebagai perwujudan dari ragam bahasa yang digunakan membuat pembelajaran tidak hanya berlangsung untuk sekadar menyampaikan materi. Pembelajaran berlangsung dengan menggunakan ragam 
bahasa yang penuh makna dan berusaha untuk menanamkan nilai-nilai karakter baik dalam diri siswa.

\section{PENUTUP}

\section{Simpulan}

Berdasarkan analisis yang dilakukan maka dapat disimpulkan beberapa hal. Pertama terkait dengan penggunaan ragam bahasa dan yang kedua terkait dengan nilai-nilai karakter yang muncul sebagai perwujudan ragam bahasa yang digunakan. Terkait dengan ragam bahasa bahwa ragam bahasa yang digunakan dalam pembelajaran di kelas XA SMA Triguna Utama adalah ragam santai, konsultatif, santai, dan satu kali ragam akrab. Kemunculan ragam tersebut didasari atas perubahan situasi dan konteks saat pembelajaran berlangsung. Beberapa karakter yang mayoritas muncul sebagai perwujudan Meskipun tidak atau belum semua nilai karakter muncul dalam kegiatan pembelajaran tetapi setidaknya guru telah berusaha menggunakan bahasa yang santun dan beragam. Alasannya jelas untuk menumbuhkan karakter siswa dan membuat kegiatan pembelajaran berjalan dengan lebih baik dan menyenangkan.

\section{Rekomendasi}

Berdasarkan simpulan tersebut maka penulis memberikan beberapa rekomendasi yang dapat diperhatikan.

Pertama, guru hendaknya memperhatikan setiap tutur kata dan memilih kata dengan baik dan santun guna menjadi teladan bagi siswa.

Kedua, sekolah hendaknya memberikan fasilitas salah satunya berupa tulisan-tulisan dengan bahasa yang baik untuk dapat menanamkan karakter dan kebiasaan baik dalam diri siswa maupun pihak-pihak lain di sekolah. Dengan begitu tindakan perundungan atau berita-berita kekerasan verbal maupun non-verbal yang melibatkan pihak sekolah akan dapat diminimalkan.

Ketiga, pemerintah dapat mengupayakan ketersediaan buku teks dengan bahasa yang baik dan memadai terutama untuk menumbukan karakter dan kebiasaan baik siswa. Buku teks dapat dilengkapi dengan nilainilai Islam (terutama untuk sekolah-sekolah di bawah Kementerian Agama). Karena seperti diketahui dan dipahami bersama bahwa Islam penuh dengan nilai-nilai kebaikan. 


\section{DAFTAR PUSTAKA}

Alamsyah, A. (2007). Pendekatan Whole Language dalam Pembelajaran Bahasa Indonesia Untuk Calon Guru Sekolah Dasar. Bahasa Dan Sastra Indonesia, 1(1).

Allard, E C, S Apt, and I. S. (2019). Language Policy and Practice in Almost-Bilingual Classrooms. International Multilingual Research Journal, 13(2), 73-83.

Hamdayama, J. (2014). Model dan Metode Pembelajaran Kreatif dan Berkarakter. Ghalia.

Hartati, S. (2019). Peningkatan Kemampuan Menyajikan Teks Berita Melalui Pembelajaran Kuantum pada Siswa Kelas VIII-6 MTs Negeri 5 Jakarta Tahun 2019. Jurnal Diklat Teknis Pendidikan dan Keagamaa, 7(2), 289-303.

Jendar, I. M. I. (2010). Sociolinguistics: The Study of Societies Language. Yogyakarta: Graha IImu. Graha Ilmu.

Kusmanto, H. (2019). Perwujudan Tindak Kesantunan Berkomentar pada Wacana Media Sosial Instagram. Jurnal Sawerigading, 25(2), 119-128.

Martati. (2019). Implementasi Prinsip-Prinsip Pendidikan dalam Islam. Andragogi: Jurnal Diklat Teknis $\begin{array}{lll}\text { Pendidikan Keagamaan, } & \text { dan (2). }\end{array}$ https://doi.org/https://doi.org/10.36052/andragogi.v7i2.91

Nuryani, Siti Isnaniah, dan I. E. (2021). Sosiolinguistik dalam Pengajaran Bahasa Berbasis Multikultural. In Media.

Nuryani. (2015). Nilai Karakter dalam Buku Pelajaran Bahasa Indonesia SMP. Prosiding Seminar Nasional Dan Launching ADOBSI.

Puspitasari , Dhika, Yunita Furinawati, dan D. R. P. (2015). Karakteristik Bahasa Lisan Siswa Kelas 1 SDN Pendem I Magetan dalam Interaksi Belajar Mengajar Tahun Ajaran 2013/2014. Jurnal Penelitian LPPM Universitas IKIP PGRI Madiun, 3(1), 5-9.

Riset, B. P. dan P. (2009). Pendidikan Budaya dan Pendidikan Karakter. Kementerian Nasional.

Rowe, L. W. (2019). Constructing Language Ideologies in a Multilingual, Second-Grade Classroom: A Case Study of Two Emergent Bilingual Students' Language-Use during EBook Composing. Linguistics and Education, 1-12. https://doi.org/https://doi.org/10.1016/j.linged.2019.05.007.

Wibowo, A. (2013). Pendidikan Karakter Berbasis Sastra. Pustaka Pelajar. 